\title{
The Effectiveness of Oral Assessment Techniques Used in EFL Classrooms in Saudi Arabia From Students and Teachers Point of View
}

\author{
Asma F. Alharbi ${ }^{1} \&$ Radhi S. Surur ${ }^{1}$ \\ ${ }^{1}$ Curriculum and Instructions Department, College of Education, King Saud University, Riyadh, Saudi Arabia \\ Correspondence: Asma F. Alharbi, Curriculum and Instructions Department, College of Education, King Saud \\ University, Riyadh, Saudi Arabia.
}

Received: December 8, 2018

Accepted: April 1, 2019 Online Published: April 3, 2019

doi: $10.5539 /$ elt.v12n5p1

URL: https://doi.org/10.5539/elt.v12n5p1

\begin{abstract}
Assessing learners' oral skills are considered as a crucial process in most EFL teaching and learning programs. However, it can be challenging for teachers to make a valid, reliable, and fair assessment. This study aimed to investigate Saudi college students' and teachers' point of views toward the effectiveness of oral assessment techniques used to assess learners speaking-skills in the EFL classroom. Two different questionnaires were administered to 12 EFL teachers and forty-two students' who are majoring in English at the Languages and Translation College at King Saud University. Both quantitative and qualitative data were collected from respondents, treated statistically, analyzed and revealed in the following sections. The findings of the study revealed that EFL teachers are using a variety of communicative oral assessment techniques and are utilizing effective assessment procedures in assessing their students' speaking skills. For students, the results revealed that students are generally satisfied with the assessment techniques and procedures that, teachers use in assessing their language performance. Recommendations and suggestions are offered for all concerned parties.
\end{abstract}

Keywords: oral assessment techniques, effectiveness, students and teachers point of view, EFL speaking ability

\section{Introduction}

Speaking skill is the most important skills in any Languages. Teachers have always faced challenges related to oral tests ranging from inadequate assessments to a lack thereof, or related to having adequate time and resources available to create thorough, fair assessments. Moreover, teachers usually spend much time trying to design productive speaking tasks, or deciding which criteria to use in making an assessment and what kind of scoring procedure they should go with. Some studies conducted in the Saudi EFL context revealed that students encounter many problems in regards to English oral tests in general such as: anxiety, not having their speaking skills assessed consistently, and not having official assessment instruction Alrabai (2014), Abu-ghararah (2014), and Al-Seghayer (2015). Therefore, a regular evaluation of assessment techniques is both fitting and essential for providing vital, fair, reliable, and valid tests for students.

Also, with ever-changing times and developments in technology come many other kinds of changes and developments. Included in these are educational developments (in both theory and practice) which call for this continual evaluation of teachers' assessment methods used in the educational process so that they may be modified and improved upon. By reviewing the literature, there are many studies which address speaking skills in regard to the difficulties and challenges faced by EFL learners and how to develop learners' oral proficiency including research conducted by Al Hosni (2014), Al-Jamal and Al-Jamal, G. A. (2013), Aljumah (2011), Hamad (2013), and Tokoz-Goktepe (2014). Further, numerous research has examined the effectiveness of specific strategies in teaching speaking skills and how it helps learners improve in these skills including: Aliakbari and Jamalvandi (2010), Correa (2015), Diyyab, Abdel-Haq and Aly (2013), Phaiboonnugulkij and Prapphal (2013), and Tuan (2012).

In light of the previously-outlined studies, it is clear that most of the studies focus on discussing and determining the challenges and difficulties faced by EFL learners in speaking skills and others focus on assessing the effectiveness of specific techniques and strategies in teaching English speaking skills. Despite this, attempts to evaluate assessment techniques and procedures, especially for speaking skills, are lacking in a Saudi context. For 
this reason, the researcher will attempt to fill this gap by presenting this study to seek the perspectives of both learners and teachers in order to have a better understanding of what techniques are being used and their effectiveness and fairness in assessing learners' performance.

\subsection{Research Questions}

The following are the research questions that are included:

1). What do teachers currently do in order to assess their students' speaking skills at Languages and Translation College in Saudi Arabia?

2). What are teachers' perceptions of their assessment methods in terms of their effectiveness?

3). What are students' perceptions of their assessment requirements in their speaking classes in Saudi Arabia?

4). How can the assessment methods be improved using the collected data from learners' and teachers' perspectives?

\section{Literature Review}

\subsection{Oral Assessment Techniques}

Assessment techniques are widely defined in the educational context. Kyra Sheahan (2012) defined assessment techniques as "quality management tools that teachers use to understand where they can make improvements or changes in the classroom in order to enable students to get the most out of their learning experience"(p. 123). The overall goal of assessment is to improve students' levels, and it can effectively help teachers to reassess themselves and their teaching techniques. Therefore, assessment should be supportive of students' strengths and have a corrective influence on students' weakness.

The value of focusing on oral assessment techniques of EFL teaching has been convincingly demonstrated by different researchers. For example, Varela and Palacios (2013) conducted a study to examine some of the best known proficiency tests in English focusing on the criteria used for the assessment of oral skills and the kinds of tasks and marking systems used for assessment. The findings indicate that there are different types of tasks that are commonly used to assess learners' oral performances, ranging from interviews to picture descriptions, topic discussions and role plays, while the criteria that are most frequently used by test takers are: range, accuracy, fluency, interaction, and coherence. Also, oral performance is commonly scored by using an analytical approach.

In contrast to Varela and Palacios' (2013) study, many others revealed negative findings related to oral assessment techniques. Ariani's study (2014) revealed that a few EFL teachers use classroom assessment techniques to assess their students, and they used final tests and judge performance based on them.

Further, Hosseini and Azarnoosh (2014) conducted a study to investigate assessment methods used by EFL teachers to assess their students' oral skills. The study revealed that the most practical oral assessment methods used by teachers are presentation and oral discussion to assess their students' oral skills. Also, the findings revealed that teachers are not making any effort to prepare assessment material, and they spend $20 \%$ percent of their total instruction time on collecting the assessment information and reporting assessment results; also, $30 \%$ out of $100 \%$ of instruction time is dedicated to recording the responses. On the same note, Sook (2003) conducted a study to identify the types and the ways of speaking assessment used by Korean English teachers. The study found that Korean English teachers did not assess students' oral proficiency from the perspective of language use and communication. This fact was reflected in the types of non-authentic speaking assessment tasks used by the Korean English teachers and in the ways they conducted speaking assessments.

In addition, Geberew (2014) carried out a study to examine the assessment techniques that teachers employed in their classroom in Ethiopia. The results revealed that only a few of the assessment techniques were employed by the teachers such as: question and answer and written assessment. In a like manner, Gonzalez, Ochoa, Cabrera, Castillo et al. (2015) carried out a study to analyze the current classroom implementation of teaching listening and speaking skills. The findings show that the most frequent speaking activities provided in the classroom were the dialogues and repetition drills. Also, it is apparent that there is not a great variety of speaking activities applied by teachers in order to develop students' oral communication.

Furthermore, Huang and $\mathrm{Hu}$ (2015) examined the attitudes of English major students and teachers towards 21 classroom activities divided into five categories: competitive activities, recreational activities, conversational activities, cooperative activities, and simulation. They found that the general perceptions of the five categories of activities have shown that the category favored most by teachers was conversational activities including: debate, mini lecture, retelling a story, and presentation, which gives learners an opportunity to communicate with their partners. While the one category liked more than other categories by students was recreational activities which 
includes English dubs, song cloze, role play, and short play, which are entertainment-oriented. Overall, students like to learn in fun ways and with games which are certainly engaging them into the learning process and helps to bring a relaxing environment to practice and improve their English language. In this regard, Huang and Hu, have recommended that it is important to consider the needs and desires of students when teachers prepare and design lessons for English speaking classes.

\subsection{Oral Assessment Criteria}

Assessment of speaking skills is widely regarded as one of the most difficult and challenging of all language skills assessment. Teachers don't know exactly which elements of speech should they consider in assessing learners' speaking skills since they must be measured in live interactions and because spoken communication involves different elements to construct effective communication. Also, communicative success depends on the speaker's ability to use them. According to Luoma (2004), "the decision about which criteria to use depends on the intended use of the test" (p. 41). Further, "teachers should not necessarily deal with all oral production in the same way. Decisions about how to react to performance will depend upon the stage of the lesson, the activity, the type of the mistake made and the particular student who is making that mistake" (Harmer, 2007, p. 123). Therefore, in order to assess speaking skills accurately, the assessment should correspond with the purpose and the type of the test. Teachers have to decide whether a particular activity applied in the classroom is designed to expect the students' complete accuracy as in the study of a piece of grammar or a pronunciation exercise or whether we are asking the students to use the language as fluency as possible. Teachers have to make a clear difference between 'non-communicative' and 'communicative' activities (Harmer, 2007). This is a vital issue because the selection of these criteria will certainly have a bearing on the validity and reliability of the test. Luoma, (2004) states that "if the participants also take part in the assessment, they need to know what criteria they should apply. One way of doing this is creating the criteria together with the examinees, or modifying a basic set of criteria that the teacher brings into the class" (p. 39).

\subsection{Scoring Procedures}

Luoma (2004) defines the scoring procedures or scales by using detailed lists of language features that can be used to describe examinees' successful performances on a task. Speaking scoring methods have been used as an assessment tool to assess learners' language performance in oral tasks and also express how well the examinees can speak the language being tested. They can be in a form of numbers or can be used as verbal categories such as 'excellent' or 'fair'. Fulcher (2003) claims that the purpose of the rating scale is to guide the rating process. There are three common scoring approaches of grading students' speech, which are: analytic, holistic, and objectified methods. The analytic approach is when the teachers rate various aspects of each student's language production separately (Brown, 1996). On the other hand, the holistic approach is to express an overall impression only of an examinee's ability in one score (Luoma, 2004). The objectified approach is to give general feedback on students' oral performance as either right or wrong without specific grade or mark (Mianto, 2006). However, this kind of scoring provides specific feedback and teachers can use this kind of scoring if they want to measures specific language features.

Accordingly, speaking skills scores have attracted considerable attention in the literature in different contexts. Tuan (2012) carried out a study to examine if the analytic scoring approach in teaching and assessing speaking would be more effective than the holistic scoring approach in improving students' speaking competence. The findings of the study indicated that students in the analytic group improved their speaking performance much better than students in the holistic group during the process of the analytic teaching and assessment and from the pretest and post-test. Tuan (2012) confirmed that the holistic scoring approach in teaching and assessing speaking does not provide useful anatomical guidance for students to improve their speaking competence. Holistic scales are practical for decision-making because they only give one score, and it makes the rating quicker than evaluating and scoring many criteria (Luoma, 2004). "The advantages of analytic scales include the detailed guidance that they give to raters, and the rich information that they provide on specific strengths and weaknesses in examinee performances" (Luoma, 2004. p 68). In contrast, both scoring approaches have limitations. The analytic approach is time-consuming and with the holistic approach, students don't know why they succeed or fail since a single score does not allow students to distinguish between various aspects of speaking (Tuan, 2012).

\subsection{Teachers' Perceptions on Oral Assessment}

\subsubsection{Problems and Challenges in Conducting Oral Assessment}

Teachers' perceptions of the feasibility of an oral assessment in any EFL program are crucial in diagnosing the ultimate success or failure of the assessment use. There is prominent research on speaking assessments from the 
point of view of the EFL teachers.

Generally, testing speaking is difficult and cannot be assessed without challenging as other language skills. Consequently, there have been many studies conducted to investigate teachers' perceptions to determine the problems encountered in oral assessment such as Sook's study (2003). He stated that teachers mentioned constraints in conducting communicative speaking assessments, such as large classes and time-consuming, excessive work in addition to classroom teaching, a lack of effective and efficient assessment instruments, students' low English proficiency, and difficulty in eliciting students' responses. Similarly, Geberew (2014) revealed the factors hindering effective implementation of various assessment techniques as reported by the interviewees. They listed that their constraints included the large class size, lack of motivation on the part of the students, and the inconvenient nature of classroom facilities.

\subsubsection{Using Multi-Measurements Techniques in Oral Assessment}

Speaking is always considered to be the most important language skill to be acquired by EFL learners because it allows speakers to convey their message and interact with other people. Therefore, assessing students' oral skill demands using a set of assessment techniques that reach all students with different levels, needs, and interests. Also, it gives more opportunities to get more valid, reliable, and consistent insight of students' progress.

Much research illustrates that EFL teachers use just a few elicitation techniques, and sometimes they use only one kind or rely on the final exam in assessing their learners' proficiency including: Ariani (2014), Sook (2003), Geberew (2014), Gonzalez, Ochoa, Cabrera et al. (2015). For instance, Sook (2003) found that teachers are using only one task for speaking assessments, which is questions and answers. Al-Seghayer's (2015) found that Saudi EFL teachers are using the traditional assessment methods such as questions and answers and reading aloud. Accordingly, they do not assess students on different aspects of the English language, such as pronunciation, fluency, use of lexis and grammar, and intelligibility. It is indicted that the reasons behind this is that teachers have no other options because of the limited time they have with the large number of students (40-50) in their classes.

\subsubsection{Necessity of a Training Course for the Oral Assessment}

With every problem and shortcomings that occurs in classroom assessment, training courses in assessment has become vitally important to support teachers in developing effective assessment practices.

Numerous research supports this claims as in Noor, Muniandy, Shanmugan, Mathai's (2010) study, which recommended training English language teachers on oral assessments. Ahmed and Alamin (2014), suggested the necessity of improving the training courses in order to promote teachers' qualifications as assessors. Also, Geberew (2014) suggested that teachers need to be given training on how to use a variety of classroom assessment techniques in order to enhance students' learning. Further, short-term courses, workshops and seminars need to be conducted and supported to increase the awareness about the classroom assessment techniques. Sook's (2003) revealed that teachers felt that one of the reasons behind discouraging them from using more communicative speaking assessment was the lack of training in conducting speaking assessment. Al-Seghayer (2011) noted that one reason of the poor quality of the English tests developed in Saudi schools is that Saudi English teachers often have little training opportunities in constructing and developing language tests, in general, and evaluating learners of English in particular.

\subsection{Students' Perceptions on Oral Assessment}

The learners' point of view is also essential and should be considered in determining the success of the learning process. Some research has focused on examining learners' perceptions on the effectiveness of various types of speaking tests including Bhati's study (2012), which aimed to study the effectiveness of oral presentation as an assessment tool compared to written assessment in a Finance subject. The major findings of this study show that students perform better in written assessment compared to oral assessment even when the topic for the group report and the oral presentation is the same. He noted that this leads to the conclusion that some students may get stressed in oral presentations which could affect their performance since oral presentations were assessed on an individual basis and students have to demonstrate their presentation skills without support from peers. This study supported the use of group work as a mechanism of study and assessment. Zhou (2012) explored the affective reactions of test-takers to a computer-delivered speaking test, specifically in regards to recording, and found that the test takers had mixed reactions. They felt a certain degree of test-taking anxiety and considered the test rather difficult, but they did enjoy the experience of taking the test and perceived it to be fair and valid.

Many studies have discussed speaking anxiety as one of the major factors that affect learners' performance including: Al Asmari (2015), Hamad (2013), Mukminin, Masbirorotni, Noprival, Sutarno, Arif and Maimunah 
(2015), Sook (2003), and Alrabai (2014). Al Asmari (2015) indicated that Saudi preparatory year students suffer from high levels of anxiety if they are involved in EFL classroom tasks without proper preparation. He advised EFL teachers to enhance the possibilities of their students' participation and practices in class tasks by offering them ample engagement opportunities on a regular basis. Also, Hamad's study (2013) revealed that students fear speaking English in public. Additionally, Mukminin, Masbirorotni, Noprival, Sutarno, Arif and Maimunah (2015) identified some sources of students' English language speaking anxiety including: fear from negative response from others, low self-esteem to speak in English, and low speaking skills due to a lack of vocabulary and grammar. Sook (2003) outlined that Korean students felt intimidated by an unfamiliarity with the test type, and also a lack of preparation for the test seemed to lead them not to reflect in their performance the best that they are capable of. On this note, Alrabia (2012) recommended that test makers to decrease the level of students anxiety to provide learners' with a relaxed testing atmosphere, that test content should range from easy to difficult, and that test instructions and grading criteria should be clear to students. Students should be exposed to practice tests before they sit for the real one and should be given sufficient time to complete their exams.

In addition to anxiety, there are variety of issues that could affect learner's performance on the speaking test. In their study, Al-Nouh, Abdul-Kareem and Taqi (2015) aimed to elicit EFL college students' perceptions of the difficulties they face in oral presentation as a form of assessment. The study indicated that students experience a number of difficulties that are mostly related to "personal traits" including students' fear of evaluation, avoidance of their instructors' eyes, and forgetting what they want to say. Also, students further complained about other difficulties such as lack of oral presentation courses, technology-based equipment, a suitable environment, and ample time allowed for the presentation.

Other studies emphasize investigating learners' preferences of the oral test type among different types as in Ychuang's study (2009) which explored Taiwanese college students' affective reactions and their attitudes toward using two different types of oral performance-based test in the English classroom. The results found that: A) test anxiety occurs when college students engage in English oral performance tests; they feel more nervous before the test than during the test. B) the majority of the students feel more comfortable when they take oral tests with a partner. C) students agree that the speaking tests which they took corresponded to what they learned in class, and their performance can more or less be affected by test format and task types. Mihye (2014) investigated Korean university EFL learners' task preferences among three different speaking tasks: "Discussion-tasks, Information-exchange tasks, and Summary tasks." It concluded that the most preferred and helpful task for students was the "Discussion task" from the three language tasks. Assessment task types could also affect learners" performance in doing the test as in Teng's study (2007), which investigated the effect of task type on the performance of EFL speaking tests for Taiwanese college students. The three task types adopted in the study consisted of answering questions, picture description, and presentation. Results revealed that students averagely felt more nervous before the task of answering questions. Also, it revealed that Taiwanese college students performed better in the EFL speaking task of answering questions by exhibiting more fluency and complexity. Further, students' perceptions of tasks also revealed that they preferred the task of picture description to others, and also, they thought the task should be included in all speaking tests. Henceforth, it is necessary to remember that assessment tasks should be implemented to bring engagement to the learning process, make it more effective and properly selected and administrated to meet all students' needs and interests.

Based on the studies discussed above, it is clear that Most of the studies discussed above, attempted to explore issues or factors that could affect the effectiveness of the oral test whether from the teachers' side or students' side. However, the researcher believes that all these factors including: teachers, students, assessment techniques and criteria, and assessment and scoring procedure, will all together affect the effectiveness of the oral assessment. Therefore, the researcher attempts to investigate both teachers' and students' point of view towards the oral assessment techniques, focusing on both types of assessment, formative and summative assessment. Also, this research focuses on teachers' assessment techniques and criteria, and assessment and scoring procedures.

\section{Research Methodology}

A mixed-method approach using quantitative and qualitative data was employed from two questionnaires, both with open-ended questions and close-ended questions.

\subsection{Research Design}

Descriptive research was used to carry out this study. Tavakoli, (2013) defines descriptive research as "an investigation that provides a picture of a phenomenon as it naturally occurs, as opposed to studying the impacts of the phenomenon or intervention. It is concerned with conditions or relationships that exist; practices that 
prevail; beliefs, points of views, or attitudes that are held; processes that are going on; effects that are being felt; or trends that are developing" (160). So, this helps in the investigating of students' and teachers' point of view on the oral assessment techniques being used in an EFL classroom.

\subsection{The Sample of the Study}

\subsubsection{Teachers}

The participants of this study included 12 female English language teachers who teach speaking as a part of their classes for different levels, and they have different experiences in teaching speaking and different qualifications. They teach in the Department of English at Languages and Translation College at King Saud University.

\subsubsection{Students}

The participants were comprised of forty-two EFL female students majoring in English in the Languages and Translation College at King Saud University, who took the course of English Listening and Speaking as one of their required courses. They were all taking two hours of English speaking classes each week. Also, they were in the fifth level of their academic studies and considered to be at the advanced level.

\subsection{Instruments}

\subsubsection{Teachers' Questionnaire}

In order to collect data about teachers' perceptions on the effectiveness of oral assessment techniques they used in their speaking classes and to examine what they did in order to assess their students speaking skills. By reviewing the literature, the researcher designed a questionnaire with both open-ended and close-ended questions which focus on four categories: oral assessment techniques, assessment criteria, scoring procedures, and assessment procedures used in assessing students' speaking skills. The questionnaire consisted of four parts using the five-point Likert scale: Never (1), Rarely (2). Sometimes (3), Often (4), Always (5). The total required time from teachers to respond to the entire questionnaire is $15-20$ minutes. Of the 16 teachers, only 12 handed in complete questionnaires.

\subsubsection{Students' Questionnaire}

In order to collect data about students' perceptions on the effectiveness of the oral assessment techniques, the researcher adapted a questionnaire from Jones, Madsen, and Brown (1980). The questionnaire consisted of 18 items using the five-point Likert scale: Strongly disagree (1), Disagree (2), No opinion (3), Agree (4), Strongly agree (5). One open-ended question was asked at the end of the questionnaire in order to fully understand their perception on the oral assessment techniques. A questionnaire was translated into Arabic and administered to students with both English and Arabic versions to ensure their understanding of the items, and the translation was verified linguistically by experts.

The total required time from students to respond to the entire questionnaire was 5-10 minutes. 50 questionnaire papers were distributed to the students and only 42 questionnaire papers were completed.

\subsection{Data Collection Procedure}

The data collection procedures went through four stages. Firstly, in an attempt to develop appropriate questionnaire instruments of this study. Both questionnaires were piloted among a small number of teachers and students to test the research process and avoid unexpected problems and allow necessary adjustment before using the final version. Further, to determine the expected time in answering the questionnaires and its validity was acquired through SPSS. Secondly, the researcher applied teachers' questionnaire in order to have a better understanding of what oral assessment techniques they used in assessing their students' speaking skills. Thirdly, after an analysis of the teachers' questionnaire responses, the advanced level of students were chosen to participate in the study questionnaire. Also, the kinds of oral assessment techniques used with this level was specified from their teacher's response in the students' questionnaire. Then, after two weeks, the students' questionnaire was applied after they finished the two projects included in their questionnaire to examine their perceptions about these two assessment techniques specifically and about all assessment procedures in general. On the whole, the data collection procedure was completed in three weeks' time.

\subsection{Validity of the Questionnaires}

The researcher applied two types of validity: face, and content validity to validate both the students' and teachers' questionnaires. Six expert referees from the same field (TESOL) and one majoring in Applied Linguistics were invited to review the two questionnaires. According to their suggestions, some items were deleted, and some of the ambiguous items were modified and clarified until the researcher came up with the final 
version of the two questionnaires.

\subsection{Reliability of the Questionnaires}

To ensure the reliability of the two questionnaires, Cronbach's Alpha, were used to test the validity of both questionnaires. It is obvious that $(0.853)$ and $(0.765)$ reflect that the reliability is suitable for the study.

\subsection{Data Analysis}

All students and teachers responses collected through the questionnaires were manually entered, coded, and analyzed using SPSS version 20. Descriptive statistics were employed to calculate frequencies, percentages, means, and standard deviations to identify the students' and teachers' point of view on oral assessment techniques used in EFL classrooms. The open-ended questions (1-6) in the teachers' questionnaire were analyzed manually. The researcher looked for common themes in the data and then grouped them under main headings.

\section{Results and Discussion}

In presenting the quantitative data of the study, percentages, frequencies, mean, and standard deviation were calculated to analyze research data. The results of the qualitative data were collected and inventoried for further description and interpretation.

\subsection{Teachers' Questionnaire}

All category data in the teachers' questionnaire are presented here including: background of teachers, oral assessment techniques, oral assessment criteria, oral scoring procedures, and oral assessment procedures.

Table 1. Background of teachers

\begin{tabular}{|c|c|c|c|c|}
\hline Teachers & $\begin{array}{l}\text { Years of teaching } \\
\text { experience }\end{array}$ & $\begin{array}{l}\text { Teaching hour per } \\
\text { week }\end{array}$ & $\begin{array}{l}\text { Grades } \\
\text { taught }\end{array}$ & $\begin{array}{l}\text { Academic } \\
\text { qualification }\end{array}$ \\
\hline Teacher 1 & 4 & 2 & 1,3 & MA \\
\hline Teacher 2 & 8 & 4 & 5 & $\mathrm{PhD}$ \\
\hline Teacher 3 & 10 & 2 & $2,4,5$ & MA \\
\hline Teacher 4 & 4 & 4 & 1,2 & MA \\
\hline Teacher 5 & 9 & 4 & 1,3 & MA \\
\hline Teacher 6 & 5 & 2 & 1,2 & MA \\
\hline Teacher 7 & 4 & 3 & $1,2,4$ & MA \\
\hline Teacher 8 & 3 & 2 & 1,2 & BA \\
\hline Teacher 9 & 5 & 3 & 3,4 & MA \\
\hline Teacher 10 & 1 & 2 & 4 & MA \\
\hline Teacher 11 & 2 & 3 & 1,3 & MA \\
\hline Teacher 12 & 1 & 2 & 3,4 & MA \\
\hline
\end{tabular}

Table 1 presents the background of the teachers, focusing on their teaching experience, teaching hours, grades taught, and their academic qualification. Table 1 shows that the teachers' experience range from one to 10 years. Teaching hours ranged from two to four and the grades taught by teachers ranged from one to five. The academic qualification of the teachers ranged from a Bachelor's degree to a $\mathrm{PhD}$, but as the table shows, only one instructor has a $\mathrm{PhD}$, one has a Bachelor's degree, and the rest (10) hold Master's Degrees. 
Table 2. Oral assessment techniques

A. Quantitative Results

\begin{tabular}{|c|c|c|c|c|c|c|c|c|}
\hline $\begin{array}{l}\text { Oral Assessment } \\
\text { Techniques }\end{array}$ & Never & Rarely & Sometimes & Often & Always & Total & Mean & SD \\
\hline \multirow{2}{*}{ 1. Presentation } & 0 & 2 & 2 & 4 & 4 & 12 & 3.8333 & 1.11464 \\
\hline & $0.00 \%$ & $16.67 \%$ & $16.67 \%$ & $33.33 \%$ & $33.33 \%$ & $100.00 \%$ & & \\
\hline \multirow{2}{*}{ 2. Oral discussion } & 0 & 0 & 0 & 3 & 9 & 12 & 4.75 & 0.45227 \\
\hline & $0.00 \%$ & $0.00 \%$ & $0.00 \%$ & $25.00 \%$ & $75.00 \%$ & $100.00 \%$ & & \\
\hline \multirow{2}{*}{ 3.Questions and answers } & 0 & 1 & 1 & 0 & 10 & 12 & 4.5833 & 0.9962 \\
\hline & $0.00 \%$ & $8.33 \%$ & $8.33 \%$ & $0.00 \%$ & $83.33 \%$ & $100.00 \%$ & & \\
\hline \multirow{2}{*}{ 4. Role play } & 0 & 2 & 3 & 3 & 4 & 12 & 3.75 & 1.13818 \\
\hline & $0.00 \%$ & $16.67 \%$ & $25.00 \%$ & $25.00 \%$ & $33.33 \%$ & $100.00 \%$ & & \\
\hline \multirow{2}{*}{ 5. Interview } & 1 & 4 & 2 & 3 & 2 & 12 & 3.0833 & 1.31137 \\
\hline & $8.33 \%$ & $33.33 \%$ & $16.67 \%$ & $25.00 \%$ & $16.67 \%$ & $100.00 \%$ & & \\
\hline \multirow{2}{*}{ 6. Story-telling } & 1 & 5 & 4 & 2 & 0 & 12 & 2.5833 & 0.90034 \\
\hline & $8.33 \%$ & $41.67 \%$ & $33.33 \%$ & $16.67 \%$ & $0.00 \%$ & $100.00 \%$ & & \\
\hline \multirow{2}{*}{ 7. Dialogue } & 0 & 2 & 1 & 5 & 4 & 12 & 3.9167 & 1.08362 \\
\hline & $0.00 \%$ & $16.67 \%$ & $8.33 \%$ & $41.67 \%$ & $33.33 \%$ & $100.00 \%$ & & \\
\hline \multirow{2}{*}{ 8. Oral reports } & 0 & 2 & 5 & 1 & 4 & 12 & 3.5833 & 1.1645 \\
\hline & $0.00 \%$ & $16.67 \%$ & $41.67 \%$ & $8.33 \%$ & $33.33 \%$ & $100.00 \%$ & & \\
\hline \multirow{2}{*}{ 9. Audio recording } & 0 & 3 & 2 & 3 & 4 & 12 & 3.6667 & 1.23091 \\
\hline & $0.00 \%$ & $25.00 \%$ & $16.67 \%$ & $25.00 \%$ & $33.33 \%$ & $100.00 \%$ & & \\
\hline \multirow{2}{*}{ 10. Picture description } & 0 & 2 & 4 & 2 & 4 & 12 & 3.6667 & 1.1547 \\
\hline & $0.00 \%$ & $16.67 \%$ & $33.33 \%$ & $16.67 \%$ & $33.33 \%$ & $100.00 \%$ & & \\
\hline \multirow{2}{*}{ 11. Simulations } & 2 & 2 & 3 & 4 & 1 & 12 & 3 & 1.2792 \\
\hline & $16.67 \%$ & $16.67 \%$ & $25.00 \%$ & $33.33 \%$ & $8.33 \%$ & $100.00 \%$ & & \\
\hline
\end{tabular}

Table 2 above reflects the oral assessment techniques used by EFL teachers in assessing their students' speaking skills. With respect to the frequency, the results shown in Table 2 reveal that the most frequent speaking techniques used by teachers are questions and answers (83.33\%) and oral discussion (75\%) followed by dialogue, presentation, role play, oral reports, audio recording, and picture description in which their means fell under the choice "often". Interview, storytelling, and simulation were the least frequent techniques used by teachers indicted from their weighted means and percentages.

In sum, data obtained from Table 2 revealed two important findings, in which English teachers used different techniques in assessing their students' speaking skill. This result is consistent with Varela and Palacios' 2013 findings. Results come in contrast with Ariani's (2014), Hosseini and Azarnoosh's (2014), Geberw (2014) and Gonzalez, Ochoa, et al. (2015) in which all their findings revealed that EFL teachers did not use a variety of assessment techniques. The second important finding is that teachers used different communicative assessment techniques such as oral discussion, role play, oral report, dialogue, picture description, and presentation. This finding is in contrast with findings by Sook (2003) in which she indicated that EFL teachers used non-authentic assessment tasks. Al-Seghayer's 2015, added “... Saudi EFL teachers used traditional assessment methods”.

B. Qualitative Results

As to the open-ended question that fell under this category, "If you use any other assessment techniques not listed above, what are they, and how do you employ them in class?" only one of the teachers said that she used debates besides some of the listed techniques in assessing students' oral performances. Also, one of the teachers indicated that audio recordings are utilized only in exams. 
Table 3. Oral assessment criteria

A. Quantitative Results

\begin{tabular}{|c|c|c|c|c|c|c|c|c|}
\hline Assessment Criteria & Never & Rarely & Sometimes & Often & Always & Total & Mean & SD \\
\hline \multirow{2}{*}{ 1. Pronunciation } & 0 & 0 & 1 & 1 & 10 & 12 & \multirow{2}{*}{4.75} & \multirow{2}{*}{0.62158} \\
\hline & $0.00 \%$ & $0.00 \%$ & $8.33 \%$ & $8.33 \%$ & $83.33 \%$ & $100.00 \%$ & & \\
\hline \multirow{2}{*}{ 2. Vocabulary } & 0 & 0 & 0 & 1 & 11 & & \multirow{2}{*}{4.9167} & \multirow{2}{*}{0.28868} \\
\hline & $0.00 \%$ & $0.00 \%$ & $0.00 \%$ & $8.33 \%$ & $91.67 \%$ & $100.00 \%$ & & \\
\hline \multirow{2}{*}{ 3. Fluency } & 0 & 0 & 1 & 3 & 8 & 12 & \multirow{2}{*}{4.5833} & \multirow{2}{*}{0.66856} \\
\hline & $0.00 \%$ & $0.00 \%$ & $8.33 \%$ & $25.00 \%$ & $66.67 \%$ & $100.00 \%$ & & \\
\hline \multirow{2}{*}{$\begin{array}{l}\text { 4.Grammar/ } \\
\text { accuracy }\end{array}$} & 0 & 0 & 0 & 1 & 11 & 12 & \multirow{2}{*}{4.9167} & \multirow{2}{*}{0.28868} \\
\hline & $0.00 \%$ & $0.00 \%$ & $0.00 \%$ & $8.33 \%$ & $91.67 \%$ & $100.00 \%$ & & \\
\hline \multirow{2}{*}{ 5. Comprehension } & 0 & 0 & 1 & 2 & 9 & 12 & \multirow{2}{*}{4.6667} & \multirow{2}{*}{0.65134} \\
\hline & $0.00 \%$ & $0.00 \%$ & $8.33 \%$ & $16.67 \%$ & $75.00 \%$ & $100.00 \%$ & & \\
\hline \multirow{2}{*}{ 6. Content } & 0 & 2 & 0 & 1 & 9 & 12 & \multirow{2}{*}{4.4167} & \multirow{2}{*}{1.1645} \\
\hline & $0.00 \%$ & $16.67 \%$ & $0.00 \%$ & $8.33 \%$ & $75.00 \%$ & $100.00 \%$ & & \\
\hline \multirow{2}{*}{ 7. Turn-taking } & 1 & 4 & 4 & 3 & 0 & 12 & \multirow{2}{*}{2.75} & \multirow{2}{*}{0.96531} \\
\hline & $8.33 \%$ & $33.33 \%$ & $33.33 \%$ & $25.00 \%$ & $0.00 \%$ & $100.00 \%$ & & \\
\hline \multirow{2}{*}{ 8. Speech production rate } & 2 & 1 & 6 & 1 & 2 & 12 & \multirow{2}{*}{3} & \multirow{2}{*}{1.2792} \\
\hline & $16.67 \%$ & $8.33 \%$ & $50.00 \%$ & $8.33 \%$ & $16.67 \%$ & $100.00 \%$ & & \\
\hline \multirow{2}{*}{ 9. Audibility } & 2 & 1 & 3 & 2 & 4 & 12 & \multirow{2}{*}{3.4167} & \multirow{2}{*}{1.50504} \\
\hline & $16.67 \%$ & $8.33 \%$ & $25.00 \%$ & $16.67 \%$ & $33.33 \%$ & $100.00 \%$ & & \\
\hline \multirow{2}{*}{ 10. Intelligibility } & 1 & 1 & 4 & 2 & 4 & 12 & \multirow{2}{*}{3.5833} & \multirow{2}{*}{1.31137} \\
\hline & $8.33 \%$ & $8.33 \%$ & $33.33 \%$ & $16.67 \%$ & $33.33 \%$ & $100.00 \%$ & & \\
\hline \multirow{2}{*}{ 11. Task completion } & 0 & 1 & 3 & 1 & 7 & 12 & \multirow{2}{*}{4.1667} & 111464 \\
\hline & $0.00 \%$ & $8.33 \%$ & $25.00 \%$ & $8.33 \%$ & $58.33 \%$ & $100.00 \%$ & & \\
\hline & 0 & 2 & 0 & 3 & 7 & 12 & & \\
\hline 12. Timing & $0.00 \%$ & $16.67 \%$ & $0.00 \%$ & $25.00 \%$ & $58.33 \%$ & $100.00 \%$ & 4.25 & 1.13818 \\
\hline
\end{tabular}

Table 3 is concerned with identifying the language criteria that teachers used in assessing students' oral performance. Table 3 reveals that the most frequent criteria used by teachers are vocabulary $(91.67 \%)$, grammar $(91.67 \%)$, pronunciation $(83.33 \%)$, comprehension $(75 \%)$, content $(75 \%)$, and fluency $(66 \%)$, where all weighted means fell under the "Always" choice. Coming in the second highest criteria used by teachers included: intelligibility, task completion, and timing, and the weighted means fell under the choice "often". In contrast, the criteria used the least by teachers were turn-taking, speech production rate, and audibility.

B. Qualitative Results

According to the open-ended questions related to the assessment criteria category "If you use different criteria for oral assessment not listed above, please write them down," Only one teacher said that she used another criteria than those listed in the table which are: arguments, confidence, and enthusiasm, which she used in assessing her students' speaking skills. The second question "Do you ever give some criteria more or less importance? If yes, what are they and why?" revealed that six teachers stated that they give some criteria more importance than others. Teacher 1 gives pronunciation, fluency, and vocabulary more importance due to the students 'advanced level and course requirements. Teacher 3 stated in her answer "I believe that the accuracy of grammar is the most important criteria, then the choice of vocabulary comes second. In placing pronunciation to be the third, it's really important to put into consideration the individual abilities of the speakers." Teacher 6 responded by saying, "I give the pronunciation more importance because it's the most important feature of speaking fluently in my opinion (Native-like). Teacher 9 said "content and vocabulary tend to overlap grammar 
and fluency." Teacher 10 respond "vocabulary and grammar more importance than other areas and specified the reasons in which students are encouraged to use a wide range of vocabulary and to present different ways of expressing a single idea. They are also asked to pay attention to grammar; they don't, however, lose points for grammatical mistakes during class practice. These two criteria are quite important because students are being trained to prepare for the translation courses where ease and accuracy of expression are highly recommended." Teacher 12 respond "comprehension more importance because being able to communicate and to be understood is an essential factor when assessing speaking."

Overall, the results show that teachers used various and different criteria in assessing students' oral performances, and this is obviously related to the various assessment tasks used by teachers, in which each task is based on specific criteria.

Table 4. Scoring procedures

A. Quantitative Results

\begin{tabular}{lllllllll}
\hline $\begin{array}{l}\text { Scoring } \\
\text { Procedures }\end{array}$ & Never & Rarely & Sometimes & Often & Always & Total & Mean & SD \\
\hline 1. Holistic scoring & 3 & 2 & 4 & 1 & 2 & 12 & 2.75 & 1.42223 \\
& $25.00 \%$ & $16.67 \%$ & $33.33 \%$ & $8.33 \%$ & $16.67 \%$ & $100.00 \%$ & & \\
2. Objectified & 4 & 4 & 3 & 1 & 0 & 12 & 2.0833 & 0.9962 \\
scoring & $33.33 \%$ & $33.33 \%$ & $25.00 \%$ & $8.33 \%$ & $0.00 \%$ & $100.00 \%$ & & \\
3. Analytic scoring & 1 & 2 & 0 & 0 & 9 & 12 & & \\
& $8.33 \%$ & $16.67 \%$ & $0.00 \%$ & $0.00 \%$ & $75.00 \%$ & $100.00 \%$ & & 1.08362 \\
\hline
\end{tabular}

Table 4 is concerned in determining the scoring procedures teachers employ in grading students' speaking skills. We can observe from the findings in Table 4 that the most frequent scoring approach used by teachers was the Analytic scoring approach, where $75 \%$ of the teachers choose the choice "always" for using analytic scoring. The Holistic scoring approach came as the second highest choice by teachers, where the weighted mean fell under the "sometimes" choice. Also, the table shows that the Objectified scoring procedure was the scoring procedure least used by teachers, where most of the teachers responses' fell between the choices "never" and "rarely".

B. Qualitative Results

According to the open-ended question related to the scoring procedures category "If you use different kinds of scoring, please write them down in detail," no one wrote that they use another kind of scoring than the three kinds listed in the table above.

In the final analysis, item 3 gained greater acceptance by most of the teachers compared to the other two kinds with (75\%) and weighted mean (4.4167). Tuan (2012) confirmed that the Analytic scoring approach in assessing speaking is effective and improves students' oral performance; however, we can't aver that this is the best scoring approach, therefore, it is necessary to conduct research to observe scoring approaches and their effectiveness.

Table 5. Oral assessment procedures

A. Quantitative Results

\begin{tabular}{lllllllll}
\hline Assessment Procedures & Never & Rarely & Sometimes & Often & Always & Total & Mean & SD \\
\hline $\begin{array}{l}1 . \quad \text { I give a clear } \\
\text { instruction }\end{array}$ & 0 & 0 & 0 & 1 & 11 & 12 & & \\
$\begin{array}{l}\text { applying the before } \\
\text { assessment. }\end{array}$ & $0.00 \%$ & $0.00 \%$ & $0.00 \%$ & $8.33 \%$ & $91.67 \%$ & $100.00 \%$ & 4.9167 & 0.28868 \\
$\begin{array}{l}\text { 2. I make sure the time } \\
\text { given to students is }\end{array}$ & 0 & 0 & 0 & 0 & 12 & 12 & & \\
enough to complete & $0.00 \%$ & $0.00 \%$ & $0.00 \%$ & $0.00 \%$ & $100.00 \%$ & $100.00 \%$ & 5 & 0 \\
\hline
\end{tabular}


assessment task.

3. I make sure to give the students space to be prepared before the ora assessment.

4. I make a careful choice $\begin{array}{lllllll}0 & 0 & 0 & 0 & 12\end{array}$ of topic and task to stimulate students interest.

\begin{tabular}{|c|c|c|c|c|c|c|c|c|}
\hline $\begin{array}{l}\text { 3. I make sure to give the } \\
\text { students space to be } \\
\text { prepared before the oral } \\
\text { assessment. }\end{array}$ & $0.00 \%$ & $0.00 \%$ & $0.00 \%$ & $0.00 \%$ & $100.00 \%$ & $100.00 \%$ & 5 & 0 \\
\hline $\begin{array}{l}\text { 4. I make a careful choice } \\
\text { of topic and task to } \\
\text { stimulate } \\
\text { interest. }\end{array}$ & $0.00 \%$ & $0.00 \%$ & $0.00 \%$ & $0.00 \%$ & $100.00 \%$ & $100.00 \%$ & 5 & 0 \\
\hline $\begin{array}{l}\text { 5. I make sure that } \\
\text { students have practiced } \\
\text { the task of the oral } \\
\text { assessment before. }\end{array}$ & $0.00 \%$ & $0.00 \%$ & $0.00 \%$ & $33.33 \%$ & $66.67 \%$ & $100.00 \%$ & 4.6667 & 0.49237 \\
\hline $\begin{array}{l}\text { 6. Ensure that test } \\
\text { questions are related to } \\
\text { the materials which have } \\
\text { been discussed in class. }\end{array}$ & $0.00 \%$ & $0.00 \%$ & $16.67 \%$ & $16.67 \%$ & $66.67 \%$ & $100.00 \%$ & 4.5 & 0.79772 \\
\hline
\end{tabular}

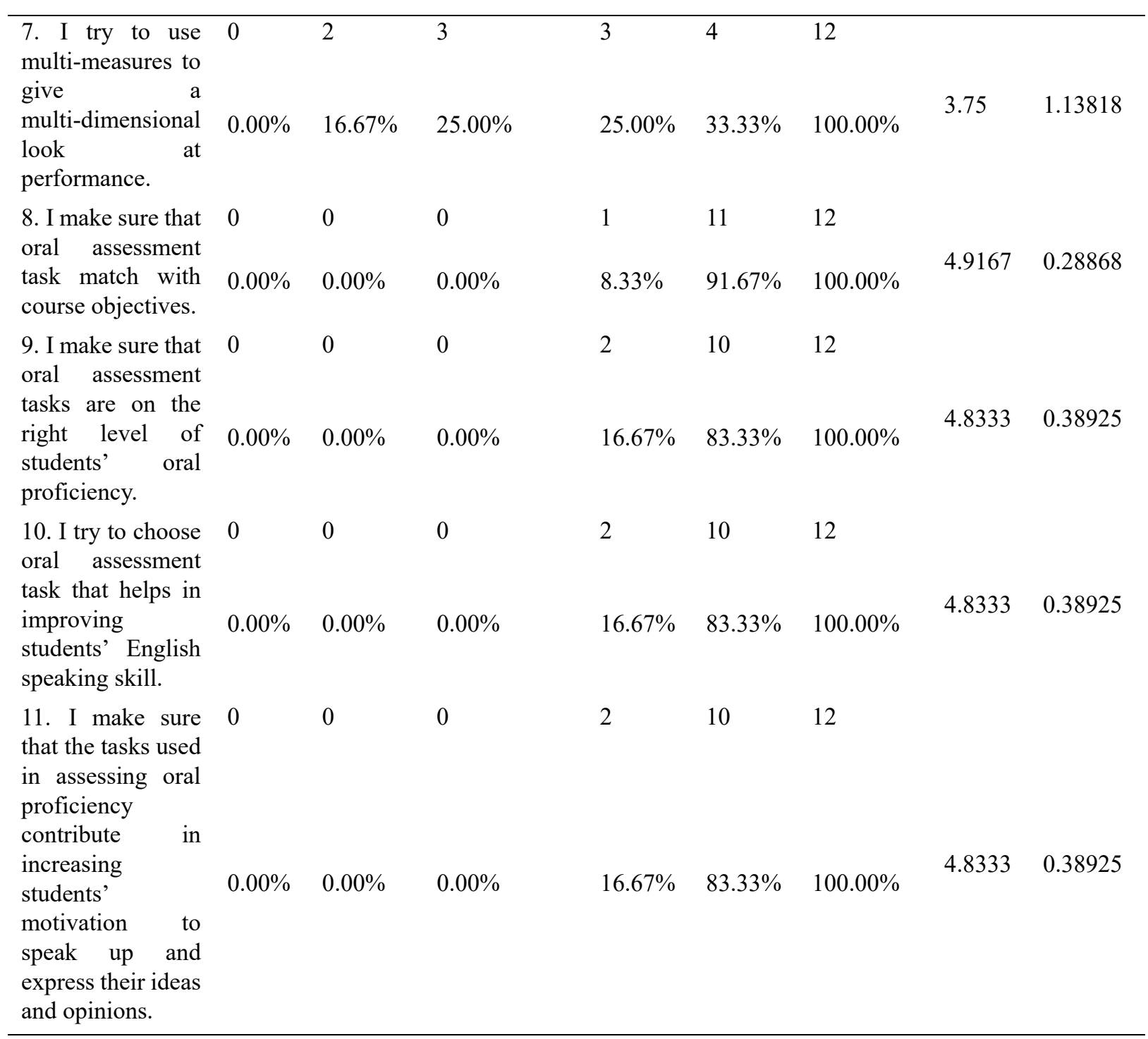


The assessment procedures category contains 11 items which are generally concerned with the effectiveness of oral assessment procedures. The results shown in Table 5 reveal that teachers' responses are quite positive, where all six items weighted means occupied the choice "always". It is obvious that all teachers give clear instruction before the test $(91.67 \%)$, give students enough time for the test (100\%), give students a space of time to prepare themselves for the test $(100 \%)$, and give more consideration to students interest in choosing the topic of the test (100\%). Further, as seen in their response to items 5 and 6 that most of the teachers choose a familiar task for students (66.67\%) and correspond to the test with the material $(66.67 \%)$.

In item 7, teachers' responses obtained from the weighted mean (3.75) goes with the choice "often" as seven teachers' responses fell between "always" and "sometimes" (58\%), and three teachers responded with "sometimes" (25\%) and only two teachers responded with "rarely" $(16.67 \%)$. This means that most of the teachers used multi-measures tools in assessing their students' oral performance. In item $8(91.76 \%)$, teachers responded with "always" making sure that oral assessment task matches with course objectives, and only one teacher respond with "often". An equal number of teachers responses were given to items 9, 10, and11, in which $11(83.33 \%)$ teachers respond with "always" with the same weighted means (4.8333) and only two (16.67\%) teachers responded with "often".

These results confirmed that most of the teachers' pay attention to students' language level while designing oral tests and choosing suitable tasks that motivate and improve students' oral proficiency. In sum, this means that teachers are making an effort in designing and conducting fair, valid, and reliable assessments.

\section{B. Qualitative Results}

The following open-ended questions were included in the teachers' questionnaire to obtain more information about their experience in assessment and about the problems teachers face in assessing their students' speaking skills.

\subsubsection{Teachers' Practices in Assessing Speaking Skills}

As to the open-ended question "How many times do you assess your students' speaking skills during the semester?" six teachers responded with three times during the semester and two teachers with four times. Two teachers responded with once a week throughout the semester. One teacher indicated that "it depends on the number of the students; if I have a small group, I assess them weekly, otherwise, I assess them four times during the semester".

Also, one teacher responded with twice for assessing achievement and weekly for assessing progress. This question was crafted to gauge whether teachers made a continuous assessment of their students' performance and progress. The findings revealed that only four teachers assess their students' progress constantly (weekly), while for eight teachers, their assessment ranged from two to three times during the semester.

Only one teacher responded with "yes" to the question "Did you use web-based tools in assessing learners" English speaking skills" saying that she used audio apps on Smartphones.

\subsubsection{Teachers' Needs of Training in Oral Assessment}

Nine of the teachers responded to the question "Have you ever attended any language assessment course or workshop?" with "yes" and only three responded with "no." This indicates that most of the teachers have had an opportunity to attend a training course on language assessment, but can't confirm the quality of theses training courses.

Regarding the question "Do you think that you may need training on how to conduct an effective oral assessment? If so, why? " most of the teachers held positive views about the training courses, where nine teachers respond with "yes" only three responded with "no." All the teachers who responded with "no" didn't provide reasons for their answers, and some of the teachers who responded with "yes" provided reasons. The following list are some of the teachers responses that clarify they need a training course in assessment.

Teacher 1: "to update my knowledge and get new insights.".

Teacher 3: "It is fine with me to attend a well-established training course."

Teacher 6: "I welcome any improvement of my teaching and assessment abilities."

Teacher 7: "I don't mind attending any course or workshop if it has something new to add to my experience."

Teacher 8: "I think there will always be new approaches that will enrich my career."

Teacher 10: "Such courses and workshops usually provide new ideas for assessment and class practice." 
Teacher 11: "Because I want to evaluate the rubric that I used for the assessment."

Teacher 12: "I would like to know if there are new ways of assessing speaking skills."

Respondents' answers lead us to two conclusions: most of the teachers welcome any improvement of their assessment techniques and want to be updated with the new ways of assessment in order to reassess themselves. Also, some of the teachers confirmed that the training course should be more helpful, effective, and well-established. On the whole, teachers' responses are quite affirmative towards the necessity of a training course in assessment, and this goes in line with the findings of Noor, Muniandy, Shanmugan, Mathai, (2010), and Ahmed and Alamin (2014).

\subsubsection{Major Problems Faced by Teachers in Oral Assessment}

For the question asking, "What are the problems and challenges you usually encounter in designing, conducting, and scoring English speaking assessments?" all teachers responded with different answers. The following list is an inventory of their responses and between brackets is the number frequency of the response by teachers.

1. Time-consuming (5)

2. Fairness (3)

3. Large classes (4)

4. Low levels of students (3)

5. Motivating students to speak naturally and fluently (2)

6. Finding appropriate material that benefits the students, is interesting, and at their levels (2)

7. Technical problems in recording and listening to students' recorded audios is a bit challenging (4)

Specifically, the problems of time-consumption, large classes, low levels of students, motivating students, and finding appropriate material are consistent with the findings of Sook (2003). Also, it is consistent with Geberew; s (2014) findings in regards to the problem of large classes and motivating students.

\subsubsection{Teachers Recommendations for the Improvement of Oral Assessment}

In order to find some remedies to the oral assessment problems and weaknesses, the researcher asked teachers to provide some recommendations that would help in improving the oral assessment techniques (See Appendix A). Recommendations obtained from teachers are listed below, after the inventory of their responses and between brackets are the frequency of their responses.

1. Reduce the number of students, minimum 15 students in each class in order to accommodate more techniques in the class (5)

2. Training teachers to use web-based or electronic tools for assessment to save teachers' time (3)

3. Find innovative methods that guarantee better performance for students and more accurate and fair assessments by teachers (4)

\subsection{Students' Questionnaire}

Table 6. Students' perceptions on oral assessment techniques in general

\begin{tabular}{|c|c|c|c|c|c|c|c|c|}
\hline $\begin{array}{l}\text { Students' perceptions } \\
\text { on oral assessment } \\
\text { techniques in general }\end{array}$ & $\begin{array}{l}\text { Strongly } \\
\text { Disagree }\end{array}$ & Disagree & $\begin{array}{l}\text { No } \\
\text { Opinion }\end{array}$ & Agree & $\begin{array}{l}\text { Strongly } \\
\text { Agree }\end{array}$ & Total & Mean & SD \\
\hline \multirow{2}{*}{$\begin{array}{l}\text { 1. I feel very anxious } \\
\text { before speaking tests. }\end{array}$} & 1 & 4 & 1 & 20 & 16 & 42 & \multirow{2}{*}{4.0952} & \multirow{2}{*}{1.00752} \\
\hline & $2.38 \%$ & $9.52 \%$ & $2.38 \%$ & $47.62 \%$ & $38.10 \%$ & $100 \%$ & & \\
\hline \multirow{2}{*}{$\begin{array}{l}\text { 2. I feel comfortable } \\
\text { when I take speaking } \\
\text { tests with another } \\
\text { student. }\end{array}$} & 5 & 10 & 5 & 16 & 6 & 42 & \multirow[b]{2}{*}{3.1905} & \multirow[b]{2}{*}{1.29234} \\
\hline & $11.90 \%$ & $23.81 \%$ & $\begin{array}{l}11 . \\
90 \%\end{array}$ & $38.10 \%$ & $14.29 \%$ & $100 \%$ & & \\
\hline \multirow{2}{*}{$\begin{array}{l}\text { 3. I understood what I } \\
\text { was supposed to do } \\
\text { during the speaking }\end{array}$} & 2 & 4 & 7 & 19 & 10 & 42 & \multirow[b]{2}{*}{3.7381} & \multirow[b]{2}{*}{1.08334} \\
\hline & $4.76 \%$ & $9.52 \%$ & $16.67 \%$ & $45.24 \%$ & $23.81 \%$ & $100 \%$ & & \\
\hline
\end{tabular}


test.

4. The test 5

corresponded to what I learned in class.

5. I am more willing to speak in class when we discuss current events.
53

$11.90 \%$ 3

0 $7.14 \%$ 2 14 17 42

$0.00 \%$
$33.33 \% \quad 40.48 \% \quad 100 \% \quad 3.8333 \quad 1.36$

$14 \quad 18 \quad 42$

4.14290 .89909

\begin{tabular}{|c|c|c|c|c|c|c|c|c|}
\hline \multirow{2}{*}{$\begin{array}{l}\text { 6. I feel more confident } \\
\text { speaking in class if we have } \\
\text { practiced more. }\end{array}$} & 1 & 2 & 1 & 14 & 24 & 42 & \multirow{2}{*}{4.381} & \multirow[b]{2}{*}{0.9358} \\
\hline & $2.38 \%$ & $4.76 \%$ & $2.38 \%$ & $33.33 \%$ & $57.14 \%$ & $100 \%$ & & \\
\hline \multirow{2}{*}{$\begin{array}{l}\text { 7. I feel anxious about the time } \\
\text { constraints. }\end{array}$} & 2 & 3 & 7 & 13 & 17 & 42 & \multirow{2}{*}{3.9524} & \multirow{2}{*}{1.14663} \\
\hline & $4.76 \%$ & $7.14 \%$ & $16.67 \%$ & $30.95 \%$ & $40.48 \%$ & $100 \%$ & & \\
\hline \multirow{2}{*}{$\begin{array}{l}\text { 8. I believe that various } \\
\text { assessment techniques gave me } \\
\text { an opportunity to do well. }\end{array}$} & 1 & 2 & 4 & 14 & 21 & 42 & \multirow[b]{2}{*}{4.2381} & \multirow[b]{2}{*}{0.98301} \\
\hline & $2.38 \%$ & $4.76 \%$ & $9.52 \%$ & $33.33 \%$ & $50.00 \%$ & $100 \%$ & & \\
\hline \multirow{2}{*}{$\begin{array}{l}\text { 9. I think the speaking test was } \\
\text { too difficult. }\end{array}$} & 16 & 13 & 9 & 2 & 2 & 42 & \multirow[t]{2}{*}{2.0714} & \multirow[t]{2}{*}{1.11296} \\
\hline & $38.10 \%$ & $30.95 \%$ & $21.43 \%$ & $4.76 \%$ & $4.76 \%$ & $100 \%$ & & \\
\hline \multirow{2}{*}{$\begin{array}{l}\text { 10. Do you think that your } \\
\text { performance can be affected } \\
\text { more or less by test format or } \\
\text { task type? }\end{array}$} & 4 & 4 & 5 & 11 & 18 & 42 & \multirow{2}{*}{3.8333} & \multirow{2}{*}{1.34194} \\
\hline & $9.52 \%$ & $9.52 \%$ & $11.90 \%$ & $26.19 \%$ & $42.86 \%$ & $100 \%$ & & \\
\hline
\end{tabular}

Item 1 to 10 in Table 6 reflects students' perceptions on the oral assessment procedures. As can be seen in Table 6 , the first item's results indicate that most of the students agreed that they feel anxious before a speaking test, where most of their choices fell between "strongly agree" and "agree" and the weighted means of their responses goes with the choice "agree." These results goes in line with many studies' findings like Zhou (2012), Al-Asmari (2015), Hamad (2013), Sook (2003), Alrabai (2014), Ychuang (2009), Bhati (2012), and Mukminin, et. al, (2015). Item 2 considers whether students feel comfortable when they take a speaking test with another student, and the results revealed that there is a discrepancy in students' responses where all their responses didn't determine their agreement or disagreement of the item, and their weighted responses fell under the "no opinion" choice. This result comes into contrast with the findings by Ychuang (2014) in which it was revealed that the majority of students feel more comfortable when they take oral tests with a partner. The results of Items 3, 4, and 5 shows students agreement where all responses weighted means goes with the choice "agree." This makes it clear that students understand teachers' instructions (68\%), they're test based on the materials they learned in the class $(73 \%)$, and they are more willing to speak in class when they discuss current events $(75 \%)$. These results confirm the findings of Sook (2003) that revealed Korean students felt intimidated by unfamiliar test types and by a lack of preparation for the test.

Item 6's results show that students are in agreement regarding who they feel more confident speaking in class if they have practiced more; 38 students answered with "strongly agree" and "agree" and their responses weighted average fell under the "agree" choice. On the other hand, Item 7 revealed that most of the students were in agreement about how they feel anxious about test time constraints as the responses' weighted means fell under the "agree" choice. Further, the results of Item 8 show that the majority of students $(88 \%)$ agreed that various assessment techniques give them an opportunity to do well. The results of Item 9 revealed that most of the students $(68 \%)$ are in disagreement when it comes to the speaking test was, which was too difficult, and only one student provided a reason in which they said," The debate task should be practiced more before the test." In addition, the results of item 10 shows that (68\%) of students agreed that their performance can be affected more or less by test format or task type. Only one student provided a reason by saying, "The test should meet students' different 
interests." The result of this item is consistent with the finding of Ychuang (2009) in which students agreed that their performance can be affect by test format and task types.

Table 7. Students' perceptions on oral presentation techniques

\begin{tabular}{|c|c|c|c|c|c|c|c|c|}
\hline $\begin{array}{l}\text { Students' perceptions } \\
\text { on oral presentation } \\
\text { technique }\end{array}$ & $\begin{array}{l}\text { Strongly } \\
\text { Disagree }\end{array}$ & Disagree & $\begin{array}{l}\text { No } \\
\text { Opinion }\end{array}$ & Agree & $\begin{array}{l}\text { Strongly } \\
\text { Agree }\end{array}$ & Total & Mean & SD \\
\hline $\begin{array}{l}\text { 1. I believe the } \\
\text { presentation technique } \\
\text { was interesting. }\end{array}$ & $\begin{array}{l}6 \\
14.29 \%\end{array}$ & $\begin{array}{l}2 \\
4.76 \%\end{array}$ & $7.14 \%$ & $\begin{array}{l}14 \\
33.33 \%\end{array}$ & $\begin{array}{l}17 \\
40.48 \%\end{array}$ & $\begin{array}{l}42 \\
100 \%\end{array}$ & 3.8095 & 1.40101 \\
\hline $\begin{array}{l}\text { 2. The given time for } \\
\text { presentation tasks was } \\
\text { enough. }\end{array}$ & $\begin{array}{l}2 \\
4.76 \%\end{array}$ & $4.76 \%$ & $9.52 \%$ & $40.48 \%$ & $40.48 \%$ & $100 \%$ & 4.0714 & 1.06823 \\
\hline $\begin{array}{l}\text { 3. I believe the } \\
\text { presentation was an } \\
\text { accurate evaluation } \\
\text { technique of my English } \\
\text { speaking skill. }\end{array}$ & $7.14 \%$ & $0.00 \%$ & $9.52 \%$ & $38.10 \%$ & $45.24 \%$ & $100 \%$ & 4.1429 & 1.09481 \\
\hline $\begin{array}{l}\text { 4. The presentation } \\
\text { technique helped me to } \\
\text { improve my speaking } \\
\text { skill. }\end{array}$ & $2.38 \%$ & $4.76 \%$ & $11.90 \%$ & $33.33 \%$ & $47.62 \%$ & $100 \%$ & 4.1905 & 0.99359 \\
\hline
\end{tabular}

The items in Table 7 reflect students' perceptions on oral presentation assessment techniques as one of their course requirements. As presented in Table 7, all four of the items obtained quite a positive response by students in which all of their responses weighted average goes with the "agree" choice. These results indicate that the majority of students saw presentation techniques as interesting $(73 \%)$, agreed that the given time for presentation was enough $(80 \%)$, the presentation was an accurate evaluation technique of their English speaking skill (83\%), and agreed that presentation techniques helped them improve their speaking skills $(80 \%)$. The finding regarding the suitability of test time are consistent with the findings by Al-Nouh et al. (2015).

Table 8. Students' perceptions on oral debate techniques

\begin{tabular}{|c|c|c|c|c|c|c|c|c|}
\hline $\begin{array}{l}\text { Students' perceptions } \\
\text { on oral debate } \\
\text { technique }\end{array}$ & $\begin{array}{l}\text { Strongly } \\
\text { Disagree }\end{array}$ & Disagree & $\begin{array}{l}\text { No } \\
\text { Opinion }\end{array}$ & Agree & $\begin{array}{l}\text { Strongly } \\
\text { Agree }\end{array}$ & Total & Mean & SD \\
\hline 1. I believe the given & 8 & 18 & 6 & 4 & 6 & 42 & \multirow[b]{2}{*}{2.5714} & \multirow[b]{2}{*}{1.30931} \\
\hline $\begin{array}{l}\text { tome } \\
\text { technique was too } \\
\text { short. }\end{array}$ & $19.05 \%$ & $42.86 \%$ & $14.29 \%$ & $9.52 \%$ & $14.29 \%$ & $100 \%$ & & \\
\hline $\begin{array}{l}\text { 2. I think that doing the } \\
\text { debate technique was }\end{array}$ & 12 & 11 & 6 & 4 & 9 & 42 & \multirow{2}{*}{2.6905} & \multirow{2}{*}{1.522} \\
\hline $\begin{array}{l}\text { an unpleasant } \\
\text { experience. }\end{array}$ & $28.57 \%$ & $26.19 \%$ & $14.29 \%$ & $9.52 \%$ & $21.43 \%$ & $100 \%$ & & \\
\hline 3. The debate & 0 & 2 & 3 & 18 & 19 & 42 & \multirow[b]{2}{*}{4.2857} & \multirow[b]{2}{*}{0.80504} \\
\hline $\begin{array}{l}\text { technique gave me an } \\
\text { opportunity to speak } \\
\text { English. }\end{array}$ & $0.00 \%$ & $4.76 \%$ & $7.14 \%$ & $42.86 \%$ & $45.24 \%$ & $100 \%$ & & \\
\hline \multirow{2}{*}{$\begin{array}{l}\text { 4. In general, I liked to } \\
\text { take part in the debate } \\
\text { technique. }\end{array}$} & 2 & 5 & 3 & 10 & 22 & 42 & \multirow[b]{2}{*}{4.0714} & \multirow[b]{2}{*}{1.23748} \\
\hline & $4.76 \%$ & $11.90 \%$ & $7.14 \%$ & $23.81 \%$ & $52.38 \%$ & $100 \%$ & & \\
\hline
\end{tabular}


The items in Table 8 are concerned with students' perceptions on oral debate techniques as one of their course requirements. The results of item 1 and 2 didn't reflect students' agreement or disagreement of these items as all students' responses weighted average fell under the "no opinion" choice. On the contrary, results obtained from Items 3 and 4 show that most students agreed that debate techniques give them an opportunity to speak English (87\%), and they liked to take part in the debate technique (75\%). Obviously, there is a discrepancy in students' responses of these four items in which they liked debate techniques, but at the same time, their response fell under the "no opinion" choice, in which debate was an unpleasant experience. Apparently, this is because that they didn't practice this task enough before the test as stated above from a student's response regarding the difficulties of the test which can be found under Table 7 in which she responded with, "The debate task should be practiced more before the test." The findings related to the debate assessment technique revealed that there is a contrast between students' responses and their teacher's response (Teacher 1) in which she responded to Item 5 by saying, "I make sure that students have practiced the task of the oral assessment before with "always."

On the whole, the findings in term of assessment procedures show that when it comes to the test corresponding to the material and clarity of test instruction. In regards to the effectiveness of the used assessment techniques, the results revealed positive findings in which the majority of the students agreed that both presentation and debate techniques gave them an opportunity to speak English and improve their performance. However, most of the students agreed that they feel anxiety before speaking tests.

Table 9. Students' preferences of oral assessment techniques

\begin{tabular}{llll}
\hline \multirow{2}{*}{ Oral Assessment Techniques } & Frequency & Total \\
\cline { 3 - 4 } & \multirow{2}{*}{ Presentation } & Percentage & 42 \\
& & 17 & $100.00 \%$ \\
$\mathbf{2}$ & Interview & $40.48 \%$ & 42 \\
& & 12 & $100.00 \%$ \\
$\mathbf{3}$ & Role-play & $28.57 \%$ & 42 \\
& & 8 & $100.00 \%$ \\
$\mathbf{4}$ & Story-telling & $19.05 \%$ & 42 \\
& & 4 & $100.00 \%$ \\
$\mathbf{5}$ & Question and answer & $9.52 \%$ & 42 \\
& & 25 & $100.00 \%$ \\
$\mathbf{6}$ & Picture description & $59.52 \%$ & 42 \\
& & 20 & $100.00 \%$ \\
$\mathbf{7}$ & Debate & $47.62 \%$ & 42 \\
& & 12 & $100.00 \%$ \\
$\mathbf{8}$ & Discussion & $28.57 \%$ & 42 \\
& & 15 & $100.00 \%$ \\
\hline
\end{tabular}

As to the last open-ended question included in the students' questionnaire, "Please put a tick beside the kind of assessment you prefer, you can choose more than one. If I could choose, I would prefer to be assessed through $a \ldots$.." the results are presented in the table above with the percentage and frequency of students' responses. As can be seen, the most preferred oral assessment techniques by students are question and answer (59.52\%), picture description (47.62\%), and presentation (40.48\%). Coming in as the second highest technique preferred by student is discussion $(35.71 \%)$, and interview and debate obtained the same frequency and percentage (28.57\%). The least preferred oral assessment techniques are role-play (19.05\%) and story-telling (9.52\%). In general, oral assessments should be deliberately designed to improve students' performance and adjust their learning progress, not merely audit their achievement at the end of the course or year. Also, the selected assessment techniques 
should bring involvement into the classroom and should be based on the purpose of the test, which should be in line with students' language levels and meet all their needs and interests.

\section{Conclusion}

This study explored teachers' and students' point of view about the effectiveness of oral assessment techniques used in EFL classrooms. Findings show that English teachers at the Language and Translation College in King Saud University used variety of communicative oral assessment techniques and utilized effective assessment procedures in assessing their students' speaking skills. However, they still face some challenges in conducting oral assessment, yet, it is encouraging to find that they welcome any kind of improvement or training courses that would be helpful in overcoming these problems. On the other hand, the findings reveal that most of the teachers didn't maintain a constant assessment of their students' performance, and they don't integrate technology into their assessment. For students, the results reveal that students are generally satisfied with the assessment techniques and procedures that, teachers used in assessing their language performance. Nevertheless, students' responses about their satisfaction with the debate techniques as one of their assessment tasks are not consistent and are in contrast with their teacher's response. Therefore, further research using different instruments such as observation is needed to make a more comprehensive review about the oral assessment techniques and procedures used in Saudi EFL classrooms.

\section{Recommendation}

The teachers' recommendations in this study are a valuable source to overcome the problems of oral assessment and to reach more effective, consistent, and valid processes. Therefore, the researcher confirmed that EFL policymakers in the Saudi context should give considerable attention to these recommendations by providing training courses on assessment in general and in oral assessment specifically. Also, it is recommended to reduce the number of students in speaking classes and equip language labs with more suitable and effective tools in order to facilitate teachers' roles and economize their time. In light of the findings, the researcher suggests that teachers have to make a constant assessment of their students oral performance to adjust their assessment methods and to diagnose students' progress in order to improve their oral performance.

\section{References}

Abu-ghararah, B. (2014). Problems with Speaking Activities in the Saudi EFL Classroom. Arab World English Journal, 5(4), 276-287.

Ahmed, S., \& Alamin, A. (2014). Assessing Speaking Ability in Academic Context for Fourth Year Taif University Students. International Journal of English Linguistics, 4(6). https://doi.org/10.5539/ijel.v4n6p97

Al Asmari, A. (2015). A Comparative Analysis of Preparatory Year Students' EFL Anxiety. International Journal of English Linguistics, 5(4), 50. https://doi.org/10.5539/ijel.v5n4p50

Al Hosni, S. (2014). Speaking Difficulties Encountered by Young EFL learners. English Language Teaching ELT.

Aliakbari, M., \& Jamalvandi, B. (2010). The Impact of” Role Play” on Fostering EFL Learners' Speaking Ability: A Task-Based Approach. Journal of Pan-Pacific Association of Applied Linguistics, 14(1), 15-29.

Al-Jamal, D. A., \& Al-Jamal, G. A. (2013). An Investigation of the Difficulties Faced by EFL Undergraduates in Speaking Skills. English Language Teaching ELT, 7(1). https://doi.org/10.5539/elt.v7n1p19

Aljumah, F. (2011). Developing Saudi EFL Students' Oral Skills: An Integrative Approach. English Language Teaching ELT, 4(3). https://doi.org/10.5539/elt.v4n3p84

Al-Nouh, N. A., Abdul-Kareem, M. M., \& Taqi, H. A. (2015). EFL College Students' Perceptions of the Difficulties in Oral Presentation as a Form of Assessment. International Journal of Higher Education, 4(1), 136. https://doi.org/10.5430/ijhe.v4n1p136

Alrabai, F. (2014). A Model of Foreign Language Anxiety in the Saudi EFL Context. English Language Teaching, 7(7), 82. https://doi.org/10.5539/elt.v7n7p82

Al-Seghayer, K. (2011). English Teaching in Saudi Arabia: Status, Issues, and Challenges. Riyadh, Saudi Arabia: Hala Printed Co.

Al-Seghayer, K. (2015). Salient key Features of Actual English Instructional Practices in Saudi Arabia. English Language Teaching, 8(6), 89. https://doi.org/10.5539/elt.v8n6p89

Ariani, M. G. (2014). Iranian EFL Teachers' Techniques to Assess Student Learning During Class. Procedia-Social and Behavioral Sciences, 158, 23-26. 
Arias, M. O. (2015). EFL Teaching in the Amazon Region of Ecuador: A Focus on Activities and Resources for Teaching Listening and Speaking Skills. English Language Teaching ELT, 8(8). https://doi.org/10. 5539/elt.v8n8p94

Bachman, L. F., \& Palmer, A. (1996). Language Testing in Practice. Oxford: OUP. https://doi.org/10.1177/ 026553229601300201

Brown, J. D. (1996). Testing in Language Programs. Upper Saddle River, NJ: Prentice Hall Regents.

Chuang, Y. Y. (2009). A study of College EFL Students' Affective Reactions and Attitudes Toward Types of Performance-Based Oral Tests. Journal of Educational Research, 43(2), 55-80.

Correa, Y. R. (2015). Skype ${ }^{\mathrm{TM}}$ Conference Calls: A Way to Promote Speaking Skills in the Teaching and Learning of English. PROFILE Issues in Teachers' Professional Development Profile, 17(1), 143-156. https://doi.org/10.15446/profile.v17n1.41856

Diyyab, E. A., Abdel-Haq, E. M., \& Aly, M. A. S. (2013). Using a Multimedia-Based Program for Developing Student Teachers' EFL Speaking Fluency Skills.

Gonzalez, P. F., Ochoa, C. A., Cabrera, P. A., Castillo, L. M., Quinonez, A. L., Solano, L. M., \& Geberew, T. M. (2014). EFL Classroom Assessment: Teachers Practice and Teaching Techniques Adjustment in Ethiopia. Educational Research and Reviews, 9(20), 1071-1089. https://doi.org/10.5897/err2014.1857

Hamad, M. M. (2013). Factors Negatively Affect Speaking Skills at Saudi Colleges for Girls in the South. English Language Teaching ELT, 6(12). https://doi.org/10.5539/elt.v6n12p87

Harmer, J. (2007). The Practice of English Language Teaching. Harlow, England: Pearson Longman. https://doi.org/10.1093/elt/ccn029

Hosseini, A. S., \& Azarnoosh, M. (2014). Iranian EFL Instructor's Oral Assessment Practices: Purposes, Methods, Procedures. Procedia-Social and Behavioral Sciences, 98, 653-658. https://doi.org/10.1016/j. sbspro.2014.03.464

Huang, X., \& Hu, X. (2015). Teachers' and Students' Perceptions of Classroom Activities Commonly Used in English Speaking Classes. Higher Education Studies HES, 6(1), 87. https://doi.org/10.5539/hes.v6n1p87

Jankowska, A., \& Zielińska, U. (2015). Designing a Self-Assessment Instrument for Developing the Speaking Skill at the Advanced Level. Issues in Teaching, Learning and Testing Speaking in a Second Language (pp. 251-265). Springer Berlin Heidelberg. https://doi.org/10.1007/978-3-642-38339-7_16

Jones, R. L., Madsen, H. S., \& Brown, B. L. (1980). Evaluation of Affective Variables in Second Language Testing. Paper presented at the 14th Annual TESOL Convention, San Francisco, CA.

Luoma, S. (2004). Assessing Speaking. Cambridge University Press. https://doi.org/10.1017/CBO9780511 733017

Madsen, H. S. (1983). Techniques in Testing. New York, NY: Oxford University Press.

Mihye, K. (2014). Korean EFL Learners' Perspectives on Speaking Tasks: Discussion, Summary, and Information-Exchange Tasks. English Language Teaching, 7(11), 1. https://doi.org/10.5539/elt.v7n11p1

Mukminin, A., Masbirorotni, M., Noprival, N., Sutarno, S., Arif, N., \& Maimunah, M. (2015). EFL Speaking Anxiety mong Senior High School Students and Policy Recommendations. Journal of Education and Learning (EduLearn), 9(3), 217-225. https://doi.org/10.11591/edulearn.v9i3.1828

Noor, N. B. M., Muniandy, M. K., Shanmugan, S. K. K., \& Mathai, E. J. (2010). Upper Primary Teachers' Perceptions of PSLE English Oral Assessment. English Language Teaching, 3(4), 142.

Phaiboonnugulkij, M., \& Prapphal, K. (2013). Online Speaking Strategy Assessment for Improving Speaking Ability in the Area of Language for Specific Purposes: The Case of Tourism. English Language Teaching ELT, 6(9). https://doi.org/10.5539/elt.v6n9p19

Tavakoli, H. (2013). A Dictionary of Research Methodology and Statistics in Applied Linguistics. Rahnama press.

Teng, H. C. (2007). A Study of Task Types for L2 Speaking Assessment.

Tokoz-Goktepe, F. (2014). Speaking Problems of 9th Grade High School Turkish Learners of L2 English and Possible Reasons for those Problems: Exploring the Teachers and Students' Perspectives. Procedia - Social and Behavioral Sciences, 116, 1875-1879. https://doi.org/10.1016/j.sbspro.2014.01.487 
Tóth, Z. (2012). Foreign Language Anxiety and Oral Performance: Differences between High-vs. Low-Anxious EFL Students. US-China Foreign Language, 10(5), 1166-1178.

Tuan, L. T. (2012). Teaching and Assessing Speaking Performance through Analytic Scoring Approach. TPLS Theory and Practice in Language Studies, 2(4). https://doi.org/10.4304/tpls.2.4.673-679

Varela, M. L., \& Palacios, I. M. (2013). How are Spoken Skills Assessed in Proficiency Tests of General English as a Foreign Language? A Preliminary Survey. International Journal of English Studies, 13(2). https://doi.org/10.6018/ijes.13.2.185901

\section{Copyrights}

Copyright for this article is retained by the author(s), with first publication rights granted to the journal.

This is an open-access article distributed under the terms and conditions of the Creative Commons Attribution license (http://creativecommons.org/licenses/by/4.0/). 